\title{
The role of melatonin in mood disorders
}

\author{
This article was published in the following Dove Press journal: \\ ChronoPhysiology and Therapy \\ II November 2015 \\ Number of times this article has been viewed
}

\section{Domenico De Berardis ${ }^{1-3}$ \\ Laura Orsolini ${ }^{3-5}$ \\ Nicola Serroni ${ }^{1}$ \\ Gabriella Girinelli ${ }^{1-3}$ \\ Felice lasevoli ${ }^{3-6}$ \\ Carmine Tomasetti ${ }^{3-6}$ \\ Monica Mazza ${ }^{3-7}$ \\ Alessandro Valchera ${ }^{3-8}$ \\ Michele Fornaro' \\ Giampaolo Perna ${ }^{10-12}$ \\ Monica Piersanti ${ }^{13}$ \\ Marco Di Nicola ${ }^{14}$ \\ Marilde Cavuto ${ }^{15}$ \\ Giovanni Martinotti² \\ Massimo Di Giannantonio²}

'NHS, Department of Mental Health, Psychiatric Service of Diagnosis and Treatment, Hospital "G Mazzini", Teramo, Italy; 'Department of Neuroscience, Imaging and Clinical Science, Chair of Psychiatry, University G d'Annunzio, Chieti, Italy; ${ }^{3}$ Polyedra, Teramo, Italy; ${ }^{4}$ United Hospitals, Academic Department of Experimental and Clinical Medicine, Polytechnic University of Marche, Ancona, Italy; ${ }^{5}$ School of Life and Medical Sciences, University of Hertfordshire, Hatfield, Hertfordshire, UK; ' 6 Laboratory of Molecular Psychiatry and Psychopharmacotherapeutics, Section of Psychiatry, Department of Neuroscience, University School of Medicine Federico II, Naples, Italy; ' Department of Health Sciences, University of L'Aquila, L'Aquila, Italy; ${ }^{8}$ Villa S Giuseppe Hospital, Hermanas Hospitalarias, Ascoli Piceno, Italy; ' Department of Scienze della Formazione, University of Catania, Catania, Italy; ${ }^{10} \mathrm{Hermanas}$ Hospitalarias, FoRiPsi, Department of Clinical Neurosciences, Villa San Benedetto Menni, Albese con Cassano, Como, Italy; "Department of Psychiatry and Neuropsychology, University of Maastricht, Maastricht, the Netherlands; ${ }^{12}$ Department of Psychiatry and Behavioral Sciences, Leonard Miller School of Medicine, University of Miami, Miami, FL, USA; ${ }^{13}$ Hospital Pharmacy, Hospital G Mazzini, ASL 4 Teramo, Italy; ${ }^{14}$ Institute of Psychiatry and Psychology, Catholic University of Sacred Heart, Rome, Italy; ${ }^{15}$ IASM, L'Aquila, Italy

Correspondence: Domenico De Berardis National Health Service, Department of Mental Health, Psychiatric Service of Diagnosis and Treatment, Hospital "G Mazzini”, Piazza Italia I, 64100 Teramo, Italy Tel +390861429708

Fax +39 086I 429709

Email dodebera@aliceposta.it
Abstract: Melatonin ( $N$-acetyl-5-methoxytryptamine) has been discovered as a hormone secreted by the pineal gland, even though it is also synthetized in various other organs, tissues, and cells. The circadian rhythm of melatonin is often used as an indicator phase position since it is a well-defined, high-amplitude rhythm controlled by the hypothalamic suprachiasmatic nuclei. Melatonin production is controlled by this endogenous circadian timing system. It peaks during the night and is suppressed by daylight. Mood spectrum disorders, including bipolar disorder (BD), major depressive disorder (MDD), and seasonal affective disorder (SAD), have been observed to be accompanied by circadian dysregulation as well as dysregulation in melatonin secretion. Simultaneously, it has also been documented that disruptions in circadian rhythms, including the sleep/wake cycle, though environmental means can produce mood-related problems in vulnerable individuals. These findings suggested that altered circadian rhythms might be biological markers of these disorders. As melatonin is considered a chronobiotic factor, ie, able to entrain the circadian rhythms of several biological functions (eg, activity/rest, sleep/wake, body temperature, endocrine rhythms, etc), its use may provide a new therapeutic approach for the treatment of affective disorders. However, the available evidence is controversial. This review summarizes the data published so far about reliable evidence on the role of melatonin in affective disorders.

Keywords: melatonin, melatonergic system, mood disorders, depression, seasonal affective disorder, bipolar disorder

\section{Introduction}

Melatonin (chemically, $N$-acetyl-5-methoxytryptamine) is an indolamine hormone isolated and characterized, in 1958, by the dermatologist Aaron Lerner who found, in extracts of bovine pineal glands, an amphibian skin-lighting factor, subsequently called melatonin due to its ability of inducing contraction of stellate amphibian melanophores. ${ }^{1}$ It is mainly synthetized, as a derivative of the amino acid tryptophan, by the parenchymal cells of the pineal gland, ${ }^{2}$ and then rapidly secreted into the blood vascular system and cerebrospinal fluid. Secondary sources are retina, gut, skin, platelets, bone marrow, and other structures..$^{3-8}$ The synthesis involves three enzymatic steps. The first is the metabolization of 1-tryptophan to serotonin (or 5-hydroxytryptamine). The second step is the $\mathrm{N}$-acetylation by the enzyme serotonin $N$-acetyltransferase (SNAT) to yield $N$-acetylserotonin. The physiological regulation of SNAT, with its sharp increase in activity at night, is considered the major regulatory step in melatonin synthesis., ${ }^{9,10}$ The final step of the synthesis pathway is the conversion of $N$-acetylserotonin to melatonin by the action of the enzyme hydroxyindole- $O$-methyltransferase (HIOMT). 
The day/night changes of HIOMT are less prominent; however, HIOMT gene transcription has also been described to have a day/night rhythm. ${ }^{11}$

Melatonin is secreted by the pineal gland by simple diffusion. Its lipophilicity contributes to its easy passive diffusion across cell membranes as well as through cell layers. ${ }^{12}$ About $60 \%-70 \%$ of melatonin in the plasma is bound to albumin. ${ }^{13,14}$ Its plasma half-life after intravenous infusion is about 30 minutes, ${ }^{15}$ but a biphasic elimination pattern with half-lives of about 3 and 45 minutes has also been observed following oral administration. ${ }^{16}$ The circulating melatonin is rapidly converted to 6-hydroxymelatonin in the liver, which clears $92 \%-97 \%$ of circulating melatonin in a single pass. The 6-hydroxymelatonin is then conjugated and excreted in urine. The sulfate derivative of 6-hydroxymelatonin accounts for $50 \%-80 \%$ of the excreted melatonin and the glucuronide derivative for $5 \%-30 \%$. The remaining melatonin is excreted either unchanged (less than 1\%), as 5-methoxyindoleacetic acid $(0.5 \%)$, or as the nonindolic metabolite $N$-acetyl-5methoxykynurenamine $(15 \%) \cdot{ }^{17,18}$

The rhythm of melatonin synthesis and secretion is entrained to a circadian period largely by the environmental alteration of light and darkness. ${ }^{19}$ Light is perceived by a subtype of retinal ganglion cells, which transmits photic stimuli to the suprachiasmatic nucleus ( $\mathrm{SCN})$ of the hypothalamus through the retino-hypothalamic tract. ${ }^{20-22}$ The SCN, in turn, conveys the signal to the pineal gland through a multisynaptic pathway and is responsible of the circadian rhythm of melatonin, which is characterized by a gradual rise suddenly after the time of lights off and by a peak at the middle of the night (around 03:00-04:00 am), with a subsequent slow decline during the second part of the night. ${ }^{19}$ This remarkable diurnal variation is also determined by the secretion of norepinephrine, released at night from postganglionic sympathetic nerves that innervate the pineal gland. The stimulation of the sympathetic nerves on the pineal gland is strictly connected to the environmental light-dark cycle., ${ }^{2,13}$ Furthermore, melatonin synthesis depends upon tryptophan availability ${ }^{23}$ and other nutritional factors such as folate status and vitamin $\mathrm{B}_{6}$, a coenzyme in tryptophan decarboxylation which is able to stimulate melatonin production. ${ }^{24-26}$

Melatonin acts through the activation of specific receptors which are called MT1 and MT2. ${ }^{27}$ They belong to the superfamily of seven-transmembrane superfamily G proteincoupled receptors. Their activation leads to the inhibition of the adenylate cyclase with subsequent decrease of intracellular cyclic adenosine monophosphate which, in turn, provokes the inhibition of protein kinase $A$ and of CREB protein phosphorylation. ${ }^{28,29}$ MT2 receptor additionally inhibits the soluble guanylyl cyclase pathway. ${ }^{30,31}$ However, depending on the tissue and species, melatonin receptor activation can elicit a variety of second messenger cascades. ${ }^{27}$ In fact, MT1 and MT2 were also found in many other tissues (eg, retina, ovary, testis, mammary gland, liver, kidney, skin, immune system, duodenum, adipocytes, myometrium, etc). ${ }^{3-8}$

Melatonin levels can be assessed by measuring its levels in blood, saliva, and by measuring its urinary metabolite, the 6-sulfatoxymelatonin (aMT6s). The most commonly used circadian melatonin phase marker is the dim light melatonin onset (DLMO). ${ }^{32}$ DLMO marks the time of the beginning of one's biological night and is also useful for assessing circadian misalignment and for phase typing. It is defined as the interpolated clock time at which the ascending phase of melatonin reaches $20 \mathrm{pg} / \mathrm{mL}$. Some authors use a cut-off of a smaller value, such as $10 \mathrm{pg} / \mathrm{mL}$ or even lower. ${ }^{33}$ The phase angle difference (PAD) between DLMO and midsleep can be used as a marker for internal circadian alignment and may also be used for phase typing. ${ }^{34}$

Affective disorders such as major depressive disorder (MDD), bipolar disorder (BD), and seasonal affective disorder (SAD) are accompanied by circadian function dysregulations, including changes in biochemical (melatonin and cortisol profiles), actigraphic (sleep/wake patterns), and dimensional (chronotypes) circadian markers, which can occur during acute mood episodes as well as during euthymic periods. ${ }^{35-37}$

In fact, in addition to the classical monoaminergic hypotheses that have been long proposed to explain the pathophysiology of mood spectrum disorders, a strong association between circadian rhythms, dysregulation in melatonin secretion, and mood regulation has been suggested in the light of several preclinical and clinical findings. ${ }^{38-47}$

There is good evidence that melatonin contributes to the entrainment of the circadian rhythms of several biological functions, including activity/rest, sleep/wake, body temperature, heart rate, liver and kidney function, and endocrine rhythms. ${ }^{45,48-50}$ Moreover, it is well documented that exogenous melatonin shows a good clinical response for reducing difficulties of falling asleep or improving symptoms associated with poorly coupled circadian rhythms, which may be present in the symptomatology of mood disorders. ${ }^{51,52}$ According to these findings, affective disorders caused by circadian dysfunction may be theoretically treatable by manipulating the circadian system using melatonin administration. ${ }^{46}$ However, there are contradictory data on its efficacy in the treatment of affective disorders. 
The present review aims to provide an overview of data published so far about the potential role of melatonin in affective disorders.

\section{Methodology/search strategy}

PubMed/Medline databases were searched by using the following sets of keywords: ([melatonin] AND [bipolar disorder OR major depression OR depression OR seasonal affective disorder OR affective disorder OR mania]). A selectively targeted literature review of English language studies was carried out. No time restrictions were placed on the electronic search covering the period up to January 2015. Secondary searches were performed using the reference list of identified papers/documents. To be included in the review, studies were required to investigate the circadian melatonin pattern (eg, its alterations) in the affective disorders (BD, MMD, or SAD). All studies not focusing on these specific topics were properly excluded, including animal studies; studies referring to melatonergic drugs; studies on population without a diagnosis of an affective disorder; studies on pregnant women, healthy subjects, or subjects affected with comorbid organic pathologies (eg, neuromuscular diseases); studies focusing on jet lag, sleep disorders, or bright light therapy. The search was performed independently by the authors. Data were compared and discrepancies were settled, if needed. Finally, data were then ranked in three macrocategories, eg, those pertaining to role of melatonin in MMD, those referring to $\mathrm{BD}$, and, finally, those regarding SAD.

With the initial set of keywords, some 1,300 studies were identified. Of these, 448 were excluded because they were either focused on preclinical/animal research (328) or were not in English language (120); whilst 674 were did not meet the inclusion criteria. Out of the remaining 181 studies, 101 were excluded because they were duplicated or were not consistent with the aims of this review, leaving a total of 80 documents to be considered for inclusion in this review. A total of 49 studies were deemed of interest for MMD, of which 30 focused on circadian dysregulation in MDD (Table 1); 16 studies referred to $\mathrm{BD}$, of which 8 referred to circadian dysregulation in $\mathrm{BD}$ (Table 2); and, finally, 15 focused on SAD, of which 9 focused on circadian dysregulation in SAD (Table 3).

\section{The role of melatonin in major depressive disorder}

Alteration of circadian rhythms in major depression, particularly unipolar depression, were first described more than 30 years ago. ${ }^{53-55}$ Several studies have later identified alterations in the melatonin secretory pattern in depression as well as in dysthymia; firstly, this suggests that, in MDD, the endogenous circadian pacemaker is set abnormally early (misaligned) with respect to the timing of sleep..$^{56,57}$ However, subsequent studies have not consistently found that the endogenous circadian pacemaker is set either abnormally early (phase advanced) or late (phase delayed) in individuals with $\mathrm{MDD}^{58}$ and that there is a large range of circadian dysregulation. In particular, the most consistent findings have been lower nocturnal melatonin levels, ${ }^{53-55,59-72}$ phase advance ${ }^{62,63,70,71,73-76}$ of melatonin onset ${ }^{77}$ or peak, ${ }^{62,63}$ a delay in the peak, ${ }^{72,75,77-80}$ onset, ${ }^{63,81,82}$ or offset $^{78}$ of melatonin secretion, as well as a longer duration of aMT6s excretion. ${ }^{78}$

According to these findings, therapeutic strategies aimed at resynchronizing the circadian clock of depressed patients have been developed, such as sleep deprivation and light therapy, ${ }^{83-86}$ even though there are contradictory findings. ${ }^{87-90}$ Furthermore, it was proposed to be a "low-melatonin syndrome". ${ }^{62,91}$ However, further studies reported that only a subgroup of depressive patients had lower melatonin levels compared to healthy subjects. ${ }^{62,68,92,93}$ These patients showed an abnormal response to dexamethasone suppression test (DST). ${ }^{62,92,94,95}$

Conversely, other studies described increased levels in melatonin concentrations in depressive patients. ${ }^{79,81,96}$ Therefore, it has been hypothesized that different melatonin patterns may reflect different subcategories of $\mathrm{MDD}^{64,82}$ and that melatonin levels may be also related to alterations in serotonin and norepinephrine levels. ${ }^{97,98}$

Furthermore, recent studies have found a relationship between severity of unipolar depression and circadian misalignment. ${ }^{80,82}$ In addition, clinical evidence that antidepressant drugs as well as mood stabilizers affect the rhythmicity of the melatonin secretion ${ }^{99-103}$ has pointed to the possibility of the involvement of melatonin in the pathophysiology of MDD. ${ }^{98,104-108}$

Finally, other studies have not demonstrated significant differences in melatonin pattern nor decrease/phase shift in MDD patients compared with healthy subjects, ${ }^{74,95,109}$ only reporting a nonsignificant trend toward higher melatonin levels in MDD patients compared with healthy subjects. ${ }^{109,110}$

Although preclinical ${ }^{111,112}$ and some clinical ${ }^{113,114}$ data supported melatonin antidepressant potentialities in rodent models, melatonin seems to lack antidepressant activity in humans. ${ }^{115}$ In fact, the few studies administering melatonin to depressed patients found improvement of sleep disturbances, but no effect on depressive symptoms ${ }^{115,116}$ nor an enhancing ${ }^{117}$ effect of existing antidepressant therapies in patients with 
Table I Melatonin circadian pattern in MDD: summary of the findings from literature

\begin{tabular}{|c|c|}
\hline Author(s) & Findings \\
\hline Mendlewicz et $\mathrm{al}^{53}$ & - Significant lower nocturnal M levels in MDD \\
\hline Wetterberg $g^{54}$ & - Significant lower nocturnal M levels in MDD \\
\hline Claustrat et a $\left.\right|^{59}$ & - Significant lower nocturnal M levels in MDD \\
\hline \multirow[t]{2}{*}{ Parry and Newton ${ }^{61}$} & - Significant lower nocturnal M levels in MDD compared to HC \\
\hline & - Estrogen treatment increases $M$ levels whilst progesterone antagonizes these effects \\
\hline \multirow[t]{2}{*}{ Beck-Friis et al ${ }^{62}$} & - Significant lower nocturnal M levels in MDD compared to HC \\
\hline & - Phase advance of $M$ onset in MDD \\
\hline \multirow[t]{2}{*}{ Nair et al ${ }^{63}$} & - Significant lower nocturnal M levels in MDD compared to HC \\
\hline & - Phase delay of M onset \\
\hline Brown et al ${ }^{64}$ & - Significant lower nocturnal M levels in MDD (melancholic subgroup) compared to HC \\
\hline Mclntyre et $\mathrm{al}^{65}$ & - Significant lower nocturnal M levels in MDD compared to HC \\
\hline Frazer et al ${ }^{66}$ & - Significant lower nocturnal M levels in MDD compared to HC \\
\hline Mclntyre et al ${ }^{67}$ & - Significant lower nocturnal M levels in MDD compared to HC \\
\hline Fountoulakis et al ${ }^{68}$ & - Significant lower nocturnal M levels in melancholic depressed patients compared to atypical and undifferentiated depressed \\
\hline Paparrigopoulos ${ }^{69}$ & - Significant lower nocturnal M levels in MDD compared to HC \\
\hline Wehr et al ${ }^{70}$ & - Phase advance of $M$ onset in MDD \\
\hline Buckley and & - Phase advance in MDD compared to HC \\
\hline Schatzberg'1 & - Significant lower nocturnal M levels in MDD compared to HC \\
\hline \multirow[t]{2}{*}{ Khaleghipour et $\mathrm{al}^{72}$} & - Significant lower nocturnal M levels in MDD compared to HC \\
\hline & - Phase delay of M peak in MDD compared to $\mathrm{HC}$ \\
\hline \multirow[t]{2}{*}{ Voderholzer et $\mathrm{al}^{74}$} & - No difference between night time levels of M in MDD and HC \\
\hline & - Phase advance of M onset in MDD \\
\hline \multirow[t]{3}{*}{ Crasson et $\mathrm{al}^{75}$} & - Significant lower nocturnal M levels in MDD compared to HC \\
\hline & - Phase-shifted M secretion in MDD compared to HC \\
\hline & - Urinary aMT6s concentrations enhanced in the morning compared to night time levels in MDD (compared to HC) \\
\hline Wehr and Goodwin ${ }^{76}$ & - Phase advance of $M$ onset in MDD \\
\hline \multirow[t]{2}{*}{ Tuunainen et a $\mathrm{l}^{78}$} & - Correlation between delayed offset of aMT6s excretion and MDD \\
\hline & - Phase delay of M offset in MDD \\
\hline Rubin et $\mathrm{al}^{77}$ & - Significant higher nocturnal M levels in MDD compared to HC \\
\hline Emens et $\mathrm{al}^{79}$ & - Phase delay of $M$ onset is correlated with depression severity \\
\hline \multirow{2}{*}{ Parry et $\mathrm{a}^{80}$} & - Increased $M$ secretion into the morning in MDD compared to HC \\
\hline & - Phase delay in MDD compared to HC \\
\hline \multirow[t]{2}{*}{ Hasler et a $\left.\right|^{81}$} & - No significant group differences in the PAD between MDD and HC \\
\hline & - A greater heterogeneity in PAD among MDD patients \\
\hline \multirow[t]{2}{*}{ Robillard et a ${ }^{82}$} & - No significant group difference in the PAD between MDD and BD \\
\hline & - Phase delay of M onset in young people with MDD and BD \\
\hline Rahman et al91 & - Low M secretion may desynchronize endogenous rhythms allowing subsyndromal MDD \\
\hline Beck-Friis et a ${ }^{92}$ & - Significant lower nocturnal M levels in MDD and BD compared to HC \\
\hline \multirow[t]{2}{*}{ Carvalho et al ${ }^{94}$} & - No significant differences in M secretion between MDD and HC \\
\hline & - No decrease nor a phase shift in MDD \\
\hline \multirow[t]{2}{*}{ Sekula et al ${ }^{110}$} & - No difference between nighttime levels of M in MDD and HC \\
\hline & - Only a trend toward higher M levels in MDD \\
\hline Shafii et $\mathrm{al}^{96}$ & - Significant higher nocturnal M levels in MDD compared to HC \\
\hline \multirow[t]{2}{*}{ Thompson et al ${ }^{109}$} & - No difference between night-time levels of M in MDD and HC \\
\hline & - Only a nonsignificant trend toward higher M levels in MDD \\
\hline
\end{tabular}

Abbreviations: PAD, phase angle difference; MDD, major depressive disorder; BD, bipolar disorder; HC, healthy controls; $M$, melatonin; aMT6s, 6-sulfatoxymelatonin.

treatment-resistant depression. ${ }^{118}$ To date, according to a recent metaanalysis, ${ }^{119}$ there is no clear evidence of a therapeutic or prophylactic effect of melatonin in MDD.

\section{The role of melatonin in bipolar disorder}

Chronobiological models have contributed to a better understanding of the pathophysiology of BD. Circadian function dysregulations, changes in the timing, and phase position are associated with BD, including melatonin secretion and sleep/ wake patterns. ${ }^{86,98,119}$ In particular, it has been noted that in manic patients phase alterations such as phase advance in melatonin levels ${ }^{120,121}$ and delayed peak melatonin secretion are accompanied by lower melatonin levels. ${ }^{86}$

Although melatonin has proved to be a reliable marker of circadian phase, few studies have focused on this measure in 
Table 2 Melatonin circadian pattern in BD: summary of the findings from literature

\begin{tabular}{|c|c|}
\hline Author(s) & Findings \\
\hline $\begin{array}{l}\text { Robillard } \\
\text { et a }{ }^{82}\end{array}$ & $\begin{array}{l}\text { - No significant group difference in the PAD between } \\
\text { MDD and BD } \\
\text { - Longer phase delay of } M \text { onset in BD compared to MDD }\end{array}$ \\
\hline Lam et $\mathrm{al}^{87}$ & $\begin{array}{l}\text { - Significant lower nocturnal M levels in BD compared } \\
\text { to } H C \text { and MDD }\end{array}$ \\
\hline $\begin{array}{l}\text { Beck-Friis } \\
\text { et al }\end{array}$ & $\begin{array}{l}\text { - Significant lower nocturnal M levels in MDD and BD } \\
\text { compared to HC }\end{array}$ \\
\hline $\begin{array}{l}\text { Lewy } \\
\text { et al }\end{array}$ & $\begin{array}{l}\text { - Significant lower nocturnal M levels in BD during } \\
\text { depressed phase } \\
\text { - Significant higher nocturnal M levels in BD during } \\
\text { manic phase } \\
\text { - Phase advance of M onset in BD }\end{array}$ \\
\hline $\begin{array}{l}\text { Kennedy } \\
\text { et } \text { al }^{12 !}\end{array}$ & $\begin{array}{l}\text { - Significant lower nocturnal M levels in BD during } \\
\text { depressed phase } \\
\text { - Significant higher nocturnal M levels in BD during } \\
\text { manic phase } \\
\text { - Phase advance of } M \text { onset in BD }\end{array}$ \\
\hline $\begin{array}{l}\text { Kennedy } \\
\text { et al }{ }^{122}\end{array}$ & $\begin{array}{l}\text { - No significant differences in M secretion among } \\
\text { several BD states } \\
\text { - Significant lower nocturnal M levels in BD compared } \\
\text { to HC } \\
\text { - No significant differences in aMT6s levels between BD } \\
\text { and HC }\end{array}$ \\
\hline $\begin{array}{l}\text { Souetre } \\
\text { et al }\left.\right|^{177}\end{array}$ & $\begin{array}{l}\text { - Significant lower nocturnal M levels in BD during } \\
\text { depressed phase } \\
\text { - Significant higher nocturnal M levels in BD during } \\
\text { manic phase } \\
\text { - Restoration of M levels during the remission of BD }\end{array}$ \\
\hline $\begin{array}{l}\text { Lewys } \\
\text { et } \mathrm{al}^{123}\end{array}$ & $\begin{array}{l}\text { - Significant lower nocturnal M levels in BD during } \\
\text { depressed phase } \\
\text { - Significant higher nocturnal M levels in BD during } \\
\text { manic phase }\end{array}$ \\
\hline
\end{tabular}

Abbreviations: PAD, phase angle difference; MDD, major depressive disorder $B D$, bipolar disorder; $M$, melatonin; $\mathrm{HC}$, healthy controls.

BD and have yielded contradictory findings. Some studies reported phase disturbances ${ }^{82,86,120,121}$ in the melatonin secretion in $\mathrm{BD}$ whilst others reported no phase variations. ${ }^{122}$ Subjects affected by BD have demonstrated significantly lower peak nocturnal melatonin levels when compared to healthy controls ${ }^{86,87,92,122}$ and unipolar depressive patients. ${ }^{87,122}$ Furthermore, both euthymic and acutely ill bipolar patients have also demonstrated a hypersensitive pineal response to ocular light exposure when compared to controls..$^{57,89}$ Some studies, which specifically evaluated patients affected with $\mathrm{BD}$, reported a reduction in melatonin secretion during the depressed phase and an increase in the manic phase of the illness whilst a restoration during the remission of symptomatology. ${ }^{120,121,123}$ These findings suggested that melatonin levels in BD might be more a "trait marker" rather than a "state marker". ${ }^{122}$

It remains unclear whether these findings indicate a primary dysfunction of the circadian timing system or whether
Table 3 Melatonin circadian pattern in SAD: summary of the findings from literature

\begin{tabular}{|c|c|}
\hline Author(s) & Findings \\
\hline \multirow[t]{2}{*}{ Lewy et $\mathrm{al}^{34}$} & - Most SAD are phase-delayed \\
\hline & - A SAD subgroup is phase-advanced \\
\hline Lewy et $\mathrm{al}^{141}$ & - Phase delay of $M$ onset during the winter in SAD \\
\hline Wehr et al ${ }^{142}$ & $\begin{array}{l}\text { - Phase delay of } M \text { onset during the winter rather } \\
\text { than summer in SAD } \\
\text { - Phase delay of M offset in SAD compared to HC }\end{array}$ \\
\hline \multicolumn{2}{|l|}{ Axelsson ${ }^{143}$} \\
\hline Danilenko et al ${ }^{144}$ & $\begin{array}{l}\text { - Higher M levels during winter in SAD compared } \\
\text { to HC }\end{array}$ \\
\hline Lewy et al $\left.\right|^{148}$ & - Phase delay of $M$ onset during the winter in SAD \\
\hline Terman et al ${ }^{149}$ & - Phase delay of $M$ onset in SAD \\
\hline Dahl et al ${ }^{150}$ & - Phase delay of M onset in SAD compared to HC \\
\hline Checkley et al ${ }^{151}$ & $\begin{array}{l}\text { - No significant differences in circadian rhythms } \\
\text { between SAD and HC }\end{array}$ \\
\hline
\end{tabular}

Abbreviations: SAD, seasonal affective disorder; $M$, melatonin; $H C$, healthy controls.

they may be secondary to sleep disturbances, a prominent characteristic in BD.

Sleep disturbance is a hallmark of BD. Sleep disturbances have been associated with a worse course of illness, ${ }^{124,125}$ increased symptom severity, and impairments in functioning and quality of life. ${ }^{124-126}$ In fact, patients affected with BD exhibit marked reduction in sleep during the night prior to switching from depressive to manic phase of the illness. ${ }^{76,127-129}$ A case report evaluation efficacy of melatonin administration in a young refractory BD patient showed relief from insomnia and manic episode. ${ }^{130}$ An open-label study reported that melatonin administration was associated with increased sleep duration as well as decrease in manic symptoms. ${ }^{129} \mathrm{~A}$ recent prospective naturalistic study reported sleep and mood improvement after administration of exogenous melatonin. ${ }^{131}$ Melatonin did not have a beneficial effect in another study conducted on bipolar patients. ${ }^{132}$

\section{The role of melatonin in seasonal affective disorder or winter depression}

The role of melatonin in the seasonal changes in physiology and behavior of various photoperiodic species has been extensively documented. ${ }^{89}$ In fact, the seasonal alterations of the natural photoperiod at high latitudes have a repercussion on melatonin secretion, ${ }^{133}$ and the melatonin rhythm is delayed during winter compared with the summer. ${ }^{134}$ Some studies reported that these alterations in melatonin secretion were also found in healthy subjects. ${ }^{135-138}$

SAD or winter depression affects upward of $10 \%$ of the population at temperate latitudes. ${ }^{139}$ It is characterized by 
recurrent depressive episodes during the short photoperiod (usually, fall/winter months) and euthymia during spring/ summer periods. Individuals with SAD are negatively affected by the shorter days and later sunrise of the winter months and develop a syndrome characterized by carbohydrate craving, lethargy, fatigue, and sadness. ${ }^{36}$

Changes in duration and/or phase of melatonin secretion during this period (the so called "phase shift hypothesis") 140 were hypothesized to play a role in the pathogenesis of SAD and prompted its treatment with phototherapy. ${ }^{141}$ In patients affected with SAD, the most prominent marker of seasonal variations may be represented by the change in the melatonin offset. ${ }^{142}$ In fact, it seems that these patients generate a biological signal indicative of the seasonal change, like photoperiodic animals do. ${ }^{142,143}$ In addition, several studies have documented higher daytime melatonin levels during the winter season in patients affected with SAD compared to healthy controls ${ }^{142-144}$ and phase delay of circadian rhythms during the winter months. ${ }^{141,142,145-150}$ However, other studies underlined no significant differences in circadian rhythms between SAD patients compared with the healthy controls evaluated. ${ }^{151}$

Although phototherapy is an effective treatment of SAD, because it induces a phase advancing ${ }^{141,144,149,150}$ of circadian rhythms by correcting the PAD between circadian and sleepwake schedules, the beneficial effect of this treatment does not seem to be supported by changes in melatonin. ${ }^{121,143,145,146,152}$
Studies focusing on efficacy of melatonin administration in SAD patients showed contradictory findings. ${ }^{153}$ In fact, although some studies reported a significant improvement of mood symptomatology; ${ }^{148,154}$ no significant differences were demonstrated after administrating exogenous melatonin compared with the placebo group. ${ }^{155,156}$ However, the phase shift hypothesis supports its efficacy in the treatment of seasonal circadian dysregulation in SAD patients, due to its capability to cause phase advances (when taken during evening) or phase delays (when taken during morning). ${ }^{34,140}$

\section{Current melatonergic drugs on the market}

In the last years, advances in medicinal chemistry led to the discovery of compounds that are specific and selective agonists and antagonists for melatonin receptors. Amongst them, some melatonergic drugs are on the market and are currently used in the clinical practice whilst others are also under evaluation (Table 4). ${ }^{157-175}$

For a more comprehensive review see Carocci et al. ${ }^{176}$

\section{Discussion and summary}

The present narrative review aimed to summarize available evidence on circadian melatonin dysregulation in affective disorders. However, the findings provided here include a large number of contradictory data. Most of the studies

Table 4 Current melatonergic drugs on the market or under evaluation

\begin{tabular}{|c|c|c|c|c|c|c|}
\hline \multirow[t]{2}{*}{ Melatonergic drug } & \multirow{2}{*}{$\begin{array}{l}\text { Trade } \\
\text { names }\end{array}$} & \multirow[t]{2}{*}{ Approval } & \multirow{2}{*}{$\begin{array}{l}\text { Pharmacological } \\
\text { actions }\end{array}$} & \multirow{2}{*}{$\begin{array}{l}\text { Chronobiotic } \\
\text { effects }\end{array}$} & \multicolumn{2}{|l|}{ Clinical effects } \\
\hline & & & & & Sleep & Mood \\
\hline Agomelatine (Servier) & $\begin{array}{l}\text { Valdoxan }^{\circledR} \\
\text { Melitor }^{\circledR} \\
\text { Thymanax }^{\circledR}\end{array}$ & $\begin{array}{l}\text { EMA } \\
(2009)\end{array}$ & $\begin{array}{l}\mathrm{MTI} / \mathrm{MT} 2 \\
\text { nonselective agonist } \\
\text { 5-HT-2 }{ }_{\mathrm{C}} \text { antagonist } \\
\text { 5-HT- } 2_{\mathrm{B}} \text { antagonist }\end{array}$ & $\begin{array}{l}\text { Phase advance and } \\
\text { entrains circadian } \\
\text { system }\end{array}$ & Significant benefits in MDD & $\begin{array}{l}\text { Significant } \\
\text { benefits in } \\
\text { MDD and SAD }\end{array}$ \\
\hline $\begin{array}{l}\text { Ramelteon (Takeda } \\
\text { Pharmaceutical Company) }\end{array}$ & Rozerem $^{\circledR}$ & $\begin{array}{l}\text { FDA } \\
(2005)\end{array}$ & $\begin{array}{l}\text { MTI/MT2 } \\
\text { nonselective agonist }\end{array}$ & Phase advance & $\begin{array}{l}\text { Significant benefits } \\
\text { in insomnia }\end{array}$ & $\mathrm{N} / \mathrm{A}$ \\
\hline $\begin{array}{l}\text { Tasimelteon (VEC-162; } \\
\text { Vanda Pharmaceuticals) }\end{array}$ & Hetlioz $^{\circledR}$ & $\begin{array}{l}\text { FDA } \\
(20 \mid 4)\end{array}$ & $\begin{array}{l}\mathrm{MTI} / \mathrm{MT2} \\
\text { nonselective agonist }\end{array}$ & $\begin{array}{l}\text { Phase advance and } \\
\text { phase delay }\end{array}$ & $\begin{array}{l}\text { Significant benefits in non- } \\
\text { 24-hour sleep-wake disorder }\end{array}$ & $N / A$ \\
\hline $\begin{array}{l}\text { TIK-30I (PD-6735, } \\
\text { LY-156, 735; Tikvah }\end{array}$ & - & - & $\begin{array}{l}\text { MTI/MT2 } \\
\text { nonselective agonist }\end{array}$ & $\begin{array}{l}\text { Promotes phase } \\
\text { advance }\end{array}$ & $\begin{array}{l}\text { Significant benefits in } \\
\text { insomnia }\end{array}$ & $N / A$ \\
\hline Pharmaceuticals) & & & & & & \\
\hline UCM765 & - & - & $\begin{array}{l}\text { MT2 selective } \\
\text { partial agonist }\end{array}$ & $N / A$ & N/A & $N / A$ \\
\hline IIK7 & - & - & $\begin{array}{l}\text { MTI/MT2 full } \\
\text { agonist }\end{array}$ & $\mathrm{N} / \mathrm{A}$ & N/A & $N / A$ \\
\hline UCM793 & - & - & $\begin{array}{l}\mathrm{MTI} / \mathrm{MT2} \\
\text { nonselective agonist }\end{array}$ & N/A & N/A & N/A \\
\hline UCM924 & - & - & $\begin{array}{l}\text { MT2 selective } \\
\text { partial agonist }\end{array}$ & $N / A$ & N/A & $N / A$ \\
\hline Neu-PII (Neurim & - & - & MTI/MT2 & N/A & $\mathrm{N} / \mathrm{A}$ & $\mathrm{N} / \mathrm{A}$ \\
\hline Pharmaceuticals Ltd) & & & nonselective agonist & & & \\
\hline
\end{tabular}

Abbreviations: EMA, European Medicines Agency; MT, melatonin receptor; MDD, major depressive disorder; SAD, seasonal affective disorder; N/A, not available; FDA, US Food and Drug Administration. 
retrieved present a greater heterogeneity in sample number and characteristics and in inclusion and exclusion criteria. For example, the extreme variability in melatonin pattern in MDD may suggest, both, the existence of different subgroups of depressive patients (eg, with different degrees of severity or a seasonal vulnerability) and an inaccurate initial selection of MDD patients (eg, an inclusion of subsyndromal BD or SAD patients). In addition, it could be argued that most data may be influenced by the choice of the age of the sample. In fact, a different circadian alignment according to the age has been reported. Another limitation may be represented by the small sample size used in most studies analyzed here, which may limit the generalizability of data.

SAD and mood disturbances (MDD and BD) caused by circadian malfunction are theoretically treatable by manipulating the circadian system using chronobiotic drugs, chronotherapy, or bright light therapy. There is no doubt that melatonin has chronobiotic properties as well as the ability to induce transient sleepiness or sleep. However, very few and contradictory evidence exist about its role in mood disorders and its potentiality in the treatment of these disorders. In fact, although melatonin appears to be well tolerated and is an effective treatment for a number of sleep disorders related to circadian rhythm disturbance, there is no conclusive confirmation about its efficacy in the treatment of mood disorders. However, due to the well-documented alterations in circadian rhythms and in melatonin secretion in mood disorders, more effective melatonin analogs (eg, agomelatine, tasimelteon, etc) have been developed and studied in order to obtain a reliable and effective drug for the treatment of mood disorders.

Further studies are necessary in order to better characterize the effect of exogenous melatonin and novel melatonergic drugs on the circadian system of MDD, BD, and SAD patients.

\section{Acknowledgments}

This paper is dedicated to Professor Venkataramanujam Srinivasan (1946-2014), a talented, smart, and intelligent researcher whose premature death has left a great void in contemporary neuroscience and melatonin research. All authors have contributed to this review with equal efforts.

\section{Disclosure}

This manuscript was entirely funded by the authors, and no pharmaceutical companies were informed of or involved in the review. The authors have no potential conflicts of interest that are directly relevant to the contents of the manuscript.

\section{References}

1. Lerner AB, Case JD, Takahashi Y, Lee TH, Mori W. Isolation of melatonin, the pineal factor that lightens melanocytes. J Am Chem Soc. 1958;89:2857-2858.

2. Reiter RJ. Pineal melatonin: cell biology of its synthesis and of its physiological interactions. Endocr Rev. 1991;12:151-180.

3. Champier J, Claustrat B, Besancon R, et al. Evidence for tryptophan hydroxylase and hydroxy-indol-O-methyl-transferase mRNAs in human blood platelets. Life Sci. 1997;60(24):2191-2197.

4. Stefulj J, Hortner M, Ghosh M, et al. Gene expression of the key enzymes of melatonin synthesis in extrapineal tissues of the rat. J Pineal Res. 2001;30(4):243-247.

5. Bubenik GA. Gastrointestinal melatonin: localization, function, and clinical relevance. Dig Dis Sci. 2002;47(10):2336-2348.

6. Slominski A, Pisarchik A, Semak I, et al. Serotoninergic and melatoninergic systems are fully expressed in human skin. FASEB J. 2002;16(8): 896-898.

7. Cardinali DP, Ladizesky MG, Boggio V, Cutrera RA, Mautalen C. Melatonin effects on bone: experimental facts and clinical perspectives. J Pineal Res. 2003;34(2):81-87.

8. Liu C, Fukuhara C, Wessel III JH, Iuvone PM, Tosini G. Localization of Aa-nat mRNA in the rat retina by fluorescence in situ hybridization and laser capture microdissection. Cell Tissue Res. 2004;315(2):197-201.

9. Klein DC, Coon SL, Roseboom PH, et al. The melatonin rhythmgenerating enzyme: molecular regulation of serotonin N-acetyltransferase in the pineal gland. Recent Prog Horm Res. 1997;52:307-357.

10. Khalil EM, De Angelis J, Ishii M, Cole PA. Mechanism-based inhibition of the melatonin rhythm enzyme: pharmacologic exploitation of active site functional plasticity. Proc Natl Acad Sci USA. 1999;96(22): 12418-12423.

11. Pévet P, Raynaud F. 5-Methoxytryptamine: physiological effects and possible mechanisms of action. In: Lukaszyk A, Reiter RJ, editors. Site of Action and Effects of Pineal Hormones. London, England: John Libbey; 1990:209-216.

12. Pardridge WM, Mietus LJ. Transport of albumin-bound melatonin through the blood-brain barrier. J Neurochem. 1980;34(6):1761-1763.

13. Cardinali DP. Melatonin. A mammalian pineal hormone. Endocr Rev. 1981;2(3):327-346.

14. Morin D, Simon N, Deprés-Brummer P, Lévi F, Tillement JP, Urien S. Melatonin highaffinity binding to alpha-1-acid glycoprotein in human serum. Pharmacology. 1997;54(5):271-275.

15. Mallo C, Zaidan R, Galy G, et al. Pharmacokinetics of melatonin in man after intravenous infusion and bolus injection. Eur J Clin Pharmacol. 1990;38(3):297-301.

16. Arendt J. Melatonin and the Mammalian Pineal Gland. London, England: Chapman and Hall; 1995.

17. Francis PL, Leone AM, Young IM, Stovell P, Silman RE. Gas chromatographic-mass spectrometric assay for 6-hydroxymelatonin sulfate and 6-hydroxymelatonin glucuronide in urine. Clin Chem. 1987; 33(4):453-457.

18. Pang SF, Lee PP, Chan YS, et al. Melatonin secretion and its rhytms in biological fluids. In: Yu HS, Reiter RJ, editors. Melatonin. Biosynthesis, Physiological effects, and Clinical Applications. Boca Raton, FL: CRC Press; 1993:129-153.

19. Wetterberg L. Light and Biological Rhythms in Man. London, England: Pergamon Press; 2014.

20. Moore RY. Neural control of the pineal gland. Behav Brain Res. 1996; 73(1-2):125-130.

21. Teclemarian-Mesbah R, Kalsbeek A, Pévet P, Buijs RM. Direct vasoactive-intestinal polypeptide-containing projection from the suprachiasmatic nucleus to spinal projecting hypothalamic paraventricular neurons projecting to the spinal cord. Brain Res. 1997;748(1-2):71-76. 
22. Berson DM, DunnFA, Takao M. Phototransduction by retinal ganglion cells that set the circadian clock. Science. 2002;295(5557):1070-1073.

23. Zimmermann RC, McDougle CJ, Schumacher M, et al. Effects of acute tryptophan depletion on nocturnal melatonin secretion in humans. J Clin Endocrinol Metab. 1993;76(5):1160-1164.

24. Munoz-Hoyos A, Amoros-Rodriguez I, Molina-Carballo A, UberosFernández J, Acuña-Castroviejo D. Pineal response after pyridoxine test in children. J Neural Transm Gen Sect. 1996;103(7):833-842.

25. Fournier I, Ploye F, Cottet-Emard JM, Brun J, Claustrat B. Folate deficiency alters melatonin secretion in rats. $J$ Nutr. 2002;132(9): 2781-2784.

26. Luboshitzky R, Ophir U, Nave R, Epstein R, Shen-Orr Z, Herer P. The effect of pyridoxine administration on melatonin secretion in normal men. Neuroendocrinol Lett. 2002;23(3):213-217.

27. Dubocovich ML, Delagrange P, Krause DN, Sugden D, Cardinali DP, Olcese J. International Union of Basic and Clinical Pharmacology. LXXV. Nomenclature, classification, and pharmacology of G proteincoupled melatonin receptors. Pharmacol Rev. 2010;62:343-380.

28. McNulty S, Ross AW, Shiu KY, Morgan PJ, Hastings MH. Phosphorylation of CREB in ovine pars tuberalis is regulated both by cyclic AMP-dependent and cyclic AMP-independent mechanisms. J Neuroendocrinol. 1996;8:635-645.

29. Reppert SM. Melatonin receptors: molecular biology of a new family of G protein-coupled receptors. J Biol Rhythms. 1997;12(6):528-531.

30. Masana MI, Dubocovich ML. Melatonin receptor signalling: finding the path through the dark. SCi STKE. 2001;2001(107):pe39.

31. von Gall C, Stehle JH, Weaver DR. Mammalian melatonin receptors: molecular biology and signal transduction. Cell Tissue Res. 2002; 309(1):151-162.

32. Benloucif S, Burgess HJ, Klerman EB, et al. Measuring melatonin in humans. J Clin Sleep Med. 2008;4:66-69.

33. Lewy AJ. The dim light melatonin onset, melatonin assays and biological rhythm research in humans. Biol Signals Recept. 1999;8:79-83.

34. Lewy AJ, Lefler BJ, Emens JS, Bauer VK. The circadian basis of winter depression. Proc Natl Acad Sci U SA. 2006;103:7414-7419.

35. Milhiet V, Boudebesse C, Bellivier F, et al. Circadian abnormalities as markers of susceptibility in bipolar disorders. Front Biosci (Schol Ed). 2014;6:120-137.

36. Malhi GS, Kuiper S. Chronobiology of mood disorders. Acta Psychiatr Scand. 2013;128(Suppl 444):2-15.

37. Srinivasan V, Smits M, Spence W, et al. Melatonin in mood disorders. World J Biol Psychiatry. 2006;7(3):138-151.

38. Kopp C, Vogel E, Rettori MC, Delagrange P, Misslin R. The effects of melatonin on the behavioural disturbances induced by chronic mild stress in C3H/He mice. Behav Pharmacol. 1999;10(1):73-83.

39. Altun A, Ugur-Altun B. Melatonin: therapeutic and clinical utilization. Int J Clin Pract. 2007;61(5):835-845.

40. Germain A, Kupfer DJ. Circadian rhythm disturbances in depression. Hum Psychopharmacol. 2008;23(7):571-585.

41. Monteleone P, Maj M. The circadian basis of mood disorders: recent developments and treatment implications. Eur Neuropsychopharmacol. 2008;18(10):701-711.

42. Etain B, Milhiet V, Bellivier F, Leboyer M. Genetics of circadian rhythms and mood spectrum disorders. Eur Neuropsychopharmacol. 2011;21(Suppl 4):S676-S682.

43. McClung CA. Circadian rhythms and mood regulation: insights from pre-clinical models. Eur Neuropsychopharmacol. 2011;21(Suppl 4): S683-S693.

44. Monteleone P, Martiadis V, Maj M. Circadian rhythms and treatment implications in depression. Prog Neuropsychopharmacol Biol Psychiatry. 2011;35(7):1569-1574.

45. Lerner AB, Nordlund JJ. Melatonin: clinical pharmacology. J Neural Transm Suppl. 1978;13:339-347.

46. Boyce P, Hopwood M. Manipulating melatonin in managing mood. Acta Psychiatr Scand. 2013;128(Suppl 444):16-23.

47. Lanfumey L, Mongeau R, Hamon M. Biological rhythms and melatonin in mood disorders and their treatments. Pharmacol Ther. 2013;138: $176-184$.
48. Richter HG, Torres-Farfán C, Rojas-García PP, Campino C, Torrealba F, Serón-Ferré M. The circadian timing system: making sense of day/night gene expression. Biol Res. 2004;37(1):11-28.

49. Quera Salva MA, Hartley S, Barbot F, Alvarez JC, Lofaso F, Guilleminault C. Circadian rhythms, melatonin and depression. Curr Pharm Des. 2011;17(15):1459-1470.

50. Mendlewicz J, Branchey I, Weinberg U, et al. The 24 hour pattern of plasma melatonin in depressed patients before and after treatment. Commun Psychopharmacol. 1980;4(1):49-55.

51. Maldonado MD, Reiter RJ, Pérez-San-Gregorio MA. Melatonin as a potential therapeutic agent in psychiatric illness. Hum Psychopharmacol. 2009;24(5):391-400.

52. Coogan AN, Thome J. Chronotherapeutics and psychiatry: setting the clock to relieve the symptoms. World J Biol Psychiatry. 2011;12(Suppl 1): $40-43$.

53. Mendlewicz J, Linkowski P, Branchey L, Weinberg U, Weitzman ED, Branchey M. Abnormal 24 hour pattern of melatonin secretion in depression. Lancet. 1979;2(8156-8157):1362.

54. Wetterberg L. Clinical importance of melatonin. Prog Brain Res. 1979;52:539-547.

55. Wirz-Justice A, Arendt J. Diurnal, menstrual cycle and seasonal indole rhythms in man and their modifications in affective disorders. In: Obiols J, Ballus C, Gonzales Monclyus E, et al, editors. Biological Psychiatry Today. Amsterdam, the Netherlands: Elsevier North-Holland; 1979: 294-302.

56. Kripke DF, Mullaney DJ, Atkinson M, Wolf S. Circadian rhythm disorders in manic-depressives. Biol Psychiatry. 1978;13:335-351.

57. Lewy AJ, Nurnberger JI Jr, Wehr TA, et al. Supersensitivity to light: possible trait marker for manic-depressive illness. Am J Psychiatry. 1985;142(6):725-727.

58. Van den Hoofdakker RH. Chronobiological theories of nonseasonal affective disorders and their implications for treatment. J Biol Rhythms. 1994;9:157-183.

59. Claustrat B, Chazot G, Brun J, Jordan D, Sassolas G. A chronobiological study of melatonin and cortisol secretion in depressed subjects: plasma melatonin, a biochemical marker in major depression. Biol Psychiatry. 1984;19:1215-1228.

60. Brown GM. Melatonin in psychiatric and sleep disorders: therapeutic implications. CNS Drugs. 1995;3:209-226.

61. Parry BL, Newton RP. Chronobiological basis of femalespecific mood disorders. Neuropsychopharmacology. 2001;25(Suppl 5): S102-S108.

62. Beck-Friis J, Kjellman BF, Aperia B et al. Serum melatonin in relation to clinical variables in patients with major depressive disorder and a hypothesis of low melatonin syndrome. Acta Psychiatr Scand. 1985;71: 319-330.

63. Nair NP, Hariharasubramanian N, Pilapil C. Circadian rhythm of plasma melatonin in endogenous depression. Prog Neuropsychopharmacol Biol Psychiatry. 1984;8(4-6):715-718.

64. Brown R, Kocsis JH, Caroff S, et al. Differences in nocturnal melatonin secretion between melancholic depressed patients and control subjects. Am J Psychiatry. 1985;142:811-816.

65. McIntyre IM, Judd FK, Norman TR, Burrows GD. Plasma melatonin concentrations in depression. Aust N Z J Psychiatry. 1986;20(3): 381-383.

66. Frazer A, Brown R, Kocsis J, et al. Patterns of melatonin rhythms in depression. J Neural Transm Suppl. 1986;21:269-290.

67. McIntyre IM, Judd FK, Marriott PM, Burrows GD, Norman TR. Plasma melatonin levels in affective states. Int J Clin Pharmacol Res. 1989;9(2): 159-164.

68. Fountoulakis KN, Karamouzis M, Iacovides A, et al. Morning and evening plasma melatonin and dexamethasone suppression test in patients with nonseasonal major depressive disorder from northern Greece (latitude 40-41.5 degrees). Neuropsychobiology. 2001;44: 113-117.

69. Paparrigopoulos T. Melatonin response to atenolol administration in depression: indication of beta-adrenoceptor dysfunction in a subtype of depression. Acta Psychiatr Scand. 2002;106:440-445. 
70. Wehr TA, Sack DA, Duncan WC et al. Sleep and circadian rhythms in affective patients isolated from external time cues. Psychiatry Res. 1985;15:327-339.

71. Buckley TM, Schatzberg AF. A pilot study of the phase angle between cortisol and melatonin in major depression - a potential biomarker? J Psychiatr Res. 2010;44(2):69-74. doi:10.1016/j. jpsychires.2009.06.012.

72. Khaleghipour S, Masjedi M, Ahade H, et al. Morning and nocturnal serum melatonin rhythm levels in patients with major depressive disorder: an analytical cross-sectional study. Sao Paulo Med J. 2012;130(3):167-172.

73. Kripke DF. Phase-advance theories for affective illness. In: Wehr TA, Goodwin FK, editors. Circadian Rhythms in Psychiatry. Pacific Grove, CA: Boxwood Press; 1983:41-69.

74. Voderholzer U, Laakmann G, Becker U, et al. Circadian profiles of melatonin in melancholic depressed patients and healthy subjects in relation to cortisol secretion and sleep. Psychiatry Res. 1997;71:151-161.

75. Crasson M, Kjiri S, Colin A, et al. Serum melatonin and urinary 6-sulfatoxy-melatonin in major depression. Psychoneuroendocrinology. 2004;29:1-12.

76. Wehr TA, Goodwin FK. Tricycles modulate frequency of mood cycles. Chronobiologia. 1979;6:377-385.

77. Rubin RT, Heist EK, McGeoy SS et al. Neuroendocrine aspects of primary endogenous depression. XI: serum melatonin measures in patients and matched control subjects. Arch Gen Psychiatry. 1992;49(7): 558-567.

78. Tuunainen A, Kripke DF, Elliott JA, et al. Depression and endogenous melatonin in postmenopausal women. J Affect Disord. 2002;69(1-3): 149-158.

79. Emens J, Lewy A, Kinzie JM, Arntz D, Rough J. Circadian misalignment in major depressive disorder. Psychiatry Res. 2009;168:259-261.

80. Parry BL, Meliska CJ, Sorenson DL, et al. Increased melatonin and delayed offset in menopausal depression: role of years past menopause, follicle-stimulating hormone, sleep end time, and body mass index. J Clin Endocrinol Metab. 2008;93(1):54-60.

81. Hasler BP, Buysse DJ, Kupfer DJ, Germain A. Phase relationships between core body temperature, melatonin, and sleep are associated with depression severity: further evidence for circadian misalignment in non-seasonal depression. Psychiatry Res. 2010;178:205-207.

82. Robillard R, Naismith SL, Rogers NL, et al. Sleep-wake cycle and melatonin rhythms in adolescents and young adults with mood disorders: comparison of unipolar and bipolar phenotypes. Eur Psychiatry. 2013;28(7):412-416. doi:10.1016/j.eurpsy.2013.04.001.

83. Wu JC, Bunney WE. The biological basis of an antidepressant response to sleep deprivation and relapse: review and hypothesis. $\mathrm{Am}$ J Psychiatry. 1990;147:14-21.

84. Kripke DF, Mullaney DJ, Klauber MR, Risch SC, Gillin JC. Controlled trial of bright light for nonseasonal major depressive disorders. Biol Psychiatry. 1992;31:119-134.

85. Benedetti F, Barbini B, Fulgosi MC, et al. Combined total sleep deprivation and light therapy in the treatment of drug-resistant bipolar depression: acute response and long-term remission rates. J Clin Psychiatry. 2005;66:1535-1540.

86. Nurnberger JI Jr, Adkins S, Lahiri DK, et al. Melatonin suppression by light in euthymic bipolar and unipolar patients. Arch Gen Psychiatry. 2000;57(6):572-579

87. Lam RW, Berkowitz AL, Berga SL, Clark CM, Kripke DF, Gillin JC. Melatonin suppression in bipolar and unipolar mood disorders. Psychiatry Res. 1990;33(2):129-134.

88. Rao ML, Müller-Oerlinghausen B, Mackert A, Strebel B, Stieglitz RD, Volz HP. Blood serotonin, serum melatonin and light therapy in healthy subjects and in patients with nonseasonal depression. Acta Psychiatr Scand. 1992;86(2):127-132.

89. Nathan PJ, Burrows GD, Norman TR. Melatonin sensitivity to dim white light in affective disorders. Neuropsychopharmacology. 1999;21(3):408-413.

90. Gordijn MC, Beersma DG, Korte HJ, van den Hoofdakker RH. Effects of light exposure and sleep displacement on dim light melatonin onset. J Sleep Res. 1999;8(3):163-174.
91. Rahman SA, Marcu S, Kayumov L, Shapiro CM. Altered sleep architecture and higher incidence of subsyndromal depression in low endogenous melatonin secretors. Eur Arch Psychiatry Clin Neurosci. 2010;260(4):327-335. doi:10.1007/s00406-009-0080-7.

92. Beck-Friis J, von Rosen D, Kjellman BF, Ljunggren JG, Wetterberg L. Melatonin in relation to body measures, sex, age, season and the use of drugs in patients with major affective disorders and healthy subjects. Psychoneuroendocrinology. 1984;9(3):261-277.

93. Waldhauser F, Ehrhart B, Forster E. Clinical aspects of the melatonin action: impact on development, aging and puberty, involvement of melatonin in psychiatric disease and importance of neuroimmunoendocrine interactions. Experientia. 1993;49:671-681.

94. Carvalho LA, Gorenstein C, Moreno RA, Markus RP. Melatonin levels in drug-free patients with major depression from the southern hemisphere. Psychoneuroendocrinology. 2006;31:761-768.

95. Carrol BJ. The dexamethasone suppression test for melancholia. $\mathrm{Br}$ J Psychiatry. 1982;140:292-304

96. Shafii M, MacMillan DR, Key MP, DerrickAM, Kaufman N, Nahinsky ID. Nocturnal serum melatonin profile in major depression in children and adolescents. Arch Gen Psychiatry. 1996;53(11):1009-1013.

97. Arendt J. Melatonin: a new probe in psychiatric investigation? Br J Psychiatry. 1989;155:585-590.

98. Srinivasan V, De Berardis D, Shillcutt SD, Brzezinski A. Role of melatonin in mood disorders and the antidepressant effects of agomelatine. Expert Opin Investig Drugs. 2012;21(10):1503-1515.

99. Thompson C, Mezey G, Corn T, et al. The effect of desipramine upon melatonin and cortisol secretion in depressed and normal subjects. $\mathrm{Br}$ J Psychiatry. 1985;147:389-393.

100. Hariharasubramanian N, Nair NP, Pilapil C, Isaac I, Quirion R. Effect of imipramine on the circadian rhythm of plasma melatonin in unipolar depression. Chronobiol Int. 1986;3(1):65-69.

101. Rabe-Jabłońska J, Szymańska A. Diurnal profile of melatonin secretion in the acute phase of major depression and in remission. $\mathrm{Med} \mathrm{Sci}$ Monit. 2001;7(5):946-952.

102. Varma A, Kaul RK, Varma P, Kalra V, Malhotra V. The effect of antidepressants on serum melatonin levels in endogenous depression. J Assoc Physicians India. 2002;50:1262-1265.

103. Carvalho LA, Gorenstein C, Moreno R, Pariante C, Markus RP. Effect of antidepressants on melatonin metabolite in depressed patients. J Psychopharmacol. 2009;23(3):315-321. doi:10.1177/0269881108089871

104. Golden RN, Markey SP, Risby ED, Rudorfer MV, Cowdry RW, Potter WZ. Antidepressants reduce whole-body norepinephrine turnover while enhancing 6-hydroxymelatonin output. Arch Gen Psychiatry. 1988;45:150-154.

105. Golden RN, Gaynes BN, Ekstrom RD, et al. The efficacy of light therapy in the treatment of mood disorders: a review and meta-analysis of the evidence. Am J Psychiatry. 2005;162:656-662.

106. Sprouse J, Braseton J, Reynolds L. Fluoxetine modulates the circadian biological clock via phase advances of suprachiasmatic nucleus neuronal firing. Biol Psychiatry. 2006;60:896-899.

107. Racagni G, Riva M, Popoli M. The interaction between the internal clock and antidepressant efficacy. Int Clin Psychopharmacol. 2007;(Suppl 2):S9-S14.

108. Li SX, Liu LJ, Xu LZ, et al. Diurnal alterations in circadian genes and peptides in major depressive disorder before and after escitalopram treatment. Psychoneuroendocrinology. 2013;38:2789-2799.

109. Thompson C, Franey C, Arendt J, Checkley SA. A comparison of melatonin secretion in depressed patients and normal subjects. $\mathrm{Br} J$ Psychiatry. 1988;152:260-265.

110. Sekula LK, Lucke JF, Heist EK, et al. Neuroendocrine aspects of primary endogenous depression. XV: Mathematical modelling of nocturnal melatonin secretion in major depressives and normal controls. Psychiatry Res. 1997;69:143-153.

111. Mantovani M, Michel Bonetti K, Calixto JB, Santos AR, Rodrigues ALS. Antidepressant-like effect of melatonin in the tail suspension test in mice: evidence for involvement of $\mathrm{N}$-methyl-D-aspartate receptors and the L-arginine-nitric oxide pathway. Neurosci Lett. 2003;343: 1-4. 
112. Micale V, Arezzi A, Rampello L, Drago F. Melatonin affects the immobility time of rats in the forced swim test: the role of serotonin neurotransmission. Eur Neuropsychopharmacol. 2006;16:538-545.

113. Kayumov L, Brown G, Jindal R, Buttoo K, Shapiro CM. A randomized, double-blind, placebo-controlled crossover study of the effect of exogenous melatonin on delayed sleep phase syndrome. Psychosom Med. 2011;63:40-48.

114. Serfaty MA, Osborne D, Buszewicz MJ, Blizard R, Raven PW. A randomized double-blind placebo-controlled trial of treatment as usual plus exogenous slow-release melatonin $(6 \mathrm{mg})$ or placebo for sleep disturbance and depressed mood. Int Clin Psychopharmacol. 2010;25:132-142.

115. Dolberg OT, Hirschmann S, Grunhaus L. Melatonin for the treatment of sleep disturbances in major depressive disorder. Am J Psychiatry. 1998;155:1119-1121.

116. de Wries MW, Peeters FP. Melatonin as a therapeutic agent in the treatment of sleep disturbances in depression. JNerv Ment Dis. 1997;185: 201-202.

117. Carman JS, Post RM, Buswell R, Goodwin FK. Negative effects of melatonin on depression. Am J Psychiatry. 1976;133:1181-1186.

118. Dalton EJ, Rotondi D, Levitan RD, Kennedy SH, Brown GM. Use of slow-release melatonin in treatment-resistant depression. JPsychiatry Neurosci. 2000;25:48-52.

119. Hansen MV, Danielsen AK, Hageman I, Rosenberg J, Gögenur I. The therapeutic or prophylactic effect of exogenous melatonin against depression and depressivesymptoms: a systematic review and meta-analysis. Eur Neuropsychopharmacol. 2014;24(11):1719-1728. doi:10.1016/j.euroneuro.2014.08.008.

120. Lewy AJ, Wehr T, Gold PW, et al. Plasma melatonin in manic depressive illness. In: Usdin E, Kopin IJ, Barchas JD, editors. Catecholamines: Basic and Clinical frontiers. Vol II. Oxford, UK: Pergamon Press; 1979:1173-1175.

121. Kennedy SH, Tighe S, McVey G, et al. Melatonin and Cortisol "switches" during mania, depression and euthymia in a drug free bipolar patient. J Nerv Ment Dis. 1989;177:300-303.

122. Kennedy SH, Kutcher SP, Ralevski E, et al. Nocturnal melatonin and 24-hour 6-sulphatoxymelatonin levels in various phases of bipolar affective disorder. Psychiatry Res. 1996;63(2-3):219-222.

123. Lewys AJ, Wehr TA, Goodwin FK, et al. Manic-depressive patients may be supersensitive to light. Lancet. 1981;1:383-384.

124. Eldelman P, Talbot LS, Gruber J, et al. Sleep, illness course, and concurrent symptoms in inter-episode bipolar disorder. J Behav Ther Exp Psychiatry. 2010;41(2):145-149.

125. Eldelman P, Talbot LS, Gruber J, et al. Sleep architecture as correlate and predictor of symptoms and impairment in inter-episode bipolar disorder: taking on the challenge of medication effects. J Sleep Res. 2010;19(4):516-524.

126. Gruber J, Harvey AG, Wang PW, et al. Sleep functioning in relation to mood, function, and quality of life at entry to the Systematic Treatment Enhancement Program for Bipolar Disorder (STEP-BD). J Affect Disord. 2009;114(1-3):41-49.

127. Bunney WE Jr, Murphy DL, Goodwin FK, et al. The Switch process from depression to mania. Relationship to drugs which alter brain monoamines. Lancet. 1970;1:1022-1027.

128. Sitaram N, Gillin JC, Bunney WE Jr. The Switch process in manicdepressive illness. Circadian variations in time of switch and sleep and manic ratings before and after switch. Acta Psychiatry Scand. 1978;58:267-278

129. Bersani G, Garavini A. Melatonin add-on in manic patients with treatment resistant insomnia. Prog Neuropsychopharmacol Biol Psychiatry. 2000;24(2):185-191.

130. Robertson JM, Tanguay PE. Case study: the use of melatonin in a boy with refractory bipolar disorder. JAm Acad Child Adolesc Psychiatry. 1997;36(6):822-825.

131. Livianos L, Sierra P, Arques S, García A, Rojo L. Is melatonin an adjunctive stabilizer? Psychiatry Clin Neurosci. 2012;66(1):82-83. doi:10.1111/j.1440-1819.2011.02288.x.
132. Leibenluft E, Feldman-Naim S, Turner EH, et al. Effects of exogenous melatonin administration and withdrawal in five patients with rapid-cycling bipolar disorder. J Clin Psychiatry. 1997;58(9): 383-388.

133. Kauppila A, Kivela A, Pakarinen A, Vakkuri O. Inverse seasonal relationship between melatonin and ovarian activity in humans in a region with a strong seasonal contrast in luminosity. J Clin Endocrinol Metab. 1987;65:823-828.

134. Yoneyama S, Hashimoto S, Honma K. Seasonal changes of human circadian rhythms in Antarctica. Am J Physiol. 1999;277:1091-1097.

135. Touitou Y, Fevre M, Bogden A, et al. Patterns of plasma melatonin with ageing and mental condition: stability of nyctohemeral rhythms and differences in seasonal variations. Acta Endocrinol (Copenh). 1984;106(2):145-151

136. Kivela A, Kauppila A, Ylostalo O, et al. Seasonal, menstrual and circadian secretions of melatonin, gonadotropins and prolactin in women. Acta Physiol Scand. 1988;132:321-327.

137. Honma K, Honma S, Kohsaka M, Fukuda N. Seasonal variation in the human circadian rhythm: dissociation between sleep and temperature rhythms. Am J Physiol. 1992;262(5 Pt 2):R885-R891.

138. Morera AL, Abreu P. Seasonality of psychopathology and circannual melatonin rhythms. J Pineal Res. 2006;41:279-283.

139. Howland RH. An overview of seasonal affective disorder and its treatment options. Phys Sportsmed. 2009;37:104-115

140. Lewy AJ, Rough JN, Songer JB, Mishra N, Yuhas K, Emens JS. The phase shift hypothesis for the circadian component of winter depression. Dialogues Clin Neurosci. 2007;9:291-300.

141. Lewy AJ, Sack RL, Miller LS, Hoban TM. Antidepressant and circadian phase shifting effects of light. Science. 1987;235:352-354.

142. Wehr TA, Duncan WC Jr, Sher L, et al. A circadian signal of change of season in patients with seasonal affective disorders. Arch Gen Psychiatry. 2001;58(12):1108-1114.

143. Káradóttir R, Axelsson J. Melatonin secretion in SAD patients and healthy subjects matched with respect to age and sex. Int J Circumpolar Health. 2001;60(4):548-551.

144. Danilenko KV, Putilov AA, Russkikh GS, Duffy LK, Ebbesson SO. Diurnal and seasonal variations of melatonin and serotonin in women with seasonal affective disorder. Arctic Med Res. 1994;53:137-145.

145. Lewy AJ, Bauer VK, Cutler NL, et al. Morning vs evening light treatment of patients with winter depression. Arch Gen Psychiatry. 1988;55(10):890-896.

146. Terman M, Terman JS. Light therapy for seasonal and nonseasonal depression: protocol, safety and side effects. CNS Spectr. 2005;10: 647-663.

147. Srinivasan V, Brzezinski A, Oter S, Shillcutt SD. Melatonin and Melatonergic Drugs in Clinical Practice. India: Springer; 2014.

148. Lewy AJ, Bauer VK, Cutler NL, Sack RL. Melatonin treatment of winter depression: a pilot study. Psychiatry Res. 1998;77:57-61.

149. Terman M, Terman JS, Quitkin FM, et al. Response of the melatonin cycle to phototherapy for seasonal affective disorder. Short note. J Neural Transm. 1988;72(2):147-165.

150. Dahl K, Avery DH, Lewy AJ, et al. Dim light melatonin onset and circadian temperature during a constant routine in hypersomnic winter depression. Acta Psychiatr Scand. 1993;88(1):60-66.

151. Checkley SA, Murphy DG, Abbas M, et al. Melatonin rhythms in seasonal affective disorder. Br J Psychiatry. 1993;163:332-337.

152. Wirz-Justice A, Graw P, Krauchi K, et al. Light therapy in seasonal affective disorder is independent of time of day or circadian phase. Arch Gen Psychiatry. 1993;50:929-937.

153. Rosenthal NE, Sack DA, Jacobsen FM, et al. Melatonin in seasonal affective disorder and phototherapy. J Neural Transm Suppl. 1986;21: 257-267.

154. Leppämäki S, Partonen T, Vakkuri O, Lönnqvist J, Partinen M, Laudon M. Effect of controlled-release melatonin on sleep quality, mood, and quality of life in subjects with seasonal or weather-associated changes in mood and behaviour. Eur Neuropsychopharmacol. 2003;13(3): $137-145$. 
155. Wirz-Justice A, Graw P, Kräuchi K, et al. Morning or night-time melatonin is ineffective in seasonal affective disorder. $J$ Psychiatr Res. 1990;24(2):129-137.

156. Danilenko KV, Putilov AA. Melatonin treatment of winter depression following total sleep deprivation: waking EEG and mood correlates. Neuropsychopharmacology. 2005;30(7):1345-1352.

157. Cardinali DP, Srinivasan V, Brzezinski A, Brown GM. Melatonin and its analogs in insomnia and depression. J Pineal Res. 2012;52: 365-375.

158. Hickie IB, Rogers NL. Novel melatonin-based therapies: potential advances in the treatment of major depression. Lancet. 2011;378(9791): 621-631.

159. Hardeland R, Poeggeler B, Srinivasan V, Trakht I, PandiPerumal SR, Cardinali DP. Melatonergic drugs in clinical practice. Arzneimittelforschung. 2008;58(1):1-10.

160. Kasper S, Hamon M. Beyond the monoaminergic hypothesis: agomelatine, a new antidepressant with an innovative mechanism of action. World J Biol Psychiatry. 2009;10(2):117-126.

161. Spadoni G, Bedini A, Rivara S, Mor M. Melatonin receptor agonists: new options for insomnia and depression treatment. CNS Neurosci Ther. 2011;17(6):733-741.

162. Catena-Dell'Osso M, Marazziti D, Rotella F, Bellantuono C. Emerging targets for the pharmacological treatment of depression: focus on melatonergic system. Curr Med Chem. 2012;19(3):428-437.

163. MacIsaac SE, Carvalho AF, Cha DS, Mansur RB, McIntyre RS. The mechanism, efficacy, and tolerability profile of agomelatine. Expert Opin Pharmacother. 2014;15(2):259-274.

164. Hale A, Corral RM, Mencacci C, Ruiz JS, Severo CA, Gentil V. Superior antidepressant efficacy results of agomelatine versus fluoxetine in severe MDD patients: a randomized, double-blind study. Int Clin Psychopharmacol. 2010;25(6):305-314.

165. Kasper S, Hajak G, Wulff K, et al. Efficacy of the novel antidepressant agomelatine on the circadian rest-activity cycle and depressive and anxiety symptoms in patients with major depressive disorder: a randomized, double-blind comparison with sertraline. J Clin Psychiatry. 2010;71(2):109-120.

166. Kato K, Hirai K, Nishiyama K, et al. Neurochemical properties of ramelteon (TAK-375), a selective MT1/MT2 receptor agonist. Neuropharmacology. 2005;48:301-310.
167. Roth T, Seiden D, Sainati S, Wang-Weigand S, Zhang J, Zee P. Effects of ramelteon on patient-reported sleep latency in older adults with chronic insomnia. Sleep Med. 2006;7:312-318.

168. Roth T, Stubbs C, Walsh JK. Ramelteon (TAK-375), a selective MT1/ MT2-receptor agonist, reduces latency to persistent sleep in a model of transient insomnia related to a novel sleep environment. Sleep. 2005;28:303-307.

169. Zammit G, Schwartz H, Roth T, Wang-Weigand S, Sainati S, Zhang J. The effects of ramelteon in a first-night model of transient insomnia Sleep Med. 2009;10:55-59.

170. Erman M, Seiden D, Zammit G, Sainati S, Zhang J. An efficacy, safety, and dose-response study of Ramelteon in patients with chronic primary insomnia. Sleep Med. 2006;7:17-24.

171. Zammit G, Erman M, Wang-Weigand S, Sainati S, Zhang J, Roth T. Evaluation of the efficacy and safety of ramelteon in subjects with chronic insomnia. J Clin Sleep Med. 2007;3:495-504.

172. Roth T, Seiden D, Wang-Weigand S, Zhang J. A 2-night, 3-period, crossover study of ramelteon's efficacy and safety in older adults with chronic insomnia. Curr Med Res Opin. 2007;23:1005-1014.

173. Vachharajani NN, Yeleswaram K, Boulton DW. Preclinical pharmacokinetics and metabolism of BMS-214778, a novel melatonin receptor agonist. J Pharm Sci. 2003;92:760-772.

174. Rajaratnam SM, Polymeropoulos MH, Fisher DM, et al. Melatonin agonist tasimelteon (VEC-162) for transient insomnia after sleep-time shift: two randomised controlled multicentre trials. Lancet. 2009;373: 482-491.

175. Rivara S, Pala D, Bedini A, Spadoni G. Therapeutic uses of melatonin and melatonin derivatives: a patent review (2012-2014). Expert Opin Ther Pat. 2015;12:1-17.

176. Carocci A, Catalano A, Sinicropi MS. Melatonergic drugs in development. Clin Pharmacol. 2014;6:127-137. doi:10.2147/CPAA. S36600.

177. Souetre E, Salvati E, Belugou JL, et al. Circadian rhythms in depression and recovery: evidence for blunted amplitude in the main chronobiological abnormality. Psychiat Res. 1989;28:263-278.
ChronoPhysiology and Therapy

\section{Publish your work in this journal}

ChronoPhysiology and Therapy is an international, peer-reviewed open access journal focusing on research into the cyclic variations and rhythmicity in physiological processes in the body and the research and development and optimal timing of administration of therapeutic targets to achieve improved outcomes and quality of life for the patient. The

\section{Dovepress}

manuscript management system is completely online and includes a very quick and fair peer-review system. Visit http://www.dovepress.com/ testimonials.php to read real quotes from published authors. 